https://doi.org/10.52058/2786-4952 -2021-4(4)-141-150

Гузій Іванна Степанівна доктор філософії, доцент кафедри педагогіки та інноваційної освіти, Національний університет «Львівська політехніка», м. Львів, вул. Чорновола, 57, корпус 36, тел.: (067) 675-93-59, e-mail: ivanna05071987@ukr.net, https://orcid.org/0000-0002-6886-6412

\title{
ЗАГАЛЬНІ ПРОБЛЕМИ ПРОФЕСІЙНОЇ ПІДГОТОВКИ МАЙБУТНІХ ФАХІВЦІВ ІНФОРМАЦІЙНОӤ, БІБЛІОТЕЧНОЇ ТА АРХІВНОЇ СПРАВИ
}

Анотація. На сучасному етапі посилюється актуальність спрямованості освітнього процесу на формування конкурентоздатних майбутніх фахівців інформаційної, бібліотечної та архівної справи у ЗВО. Суспільство прискореного отримання інформації наголошує на беззаперечних вигодах людства від масового, поверхового поширення освіти, нерідко забуваючи при цьому про не менш безперечні негативи, а то й просто втрати, якими супроводжується цей процес. Система вищої освіти України "нині модернізується на основі європейських освітніх стандартів: академічної мобільності і доброчесності, міжгалузевих компетентностей випускника, уніфікації, єдності змісту та форм, освітньо-наукового забезпечення мобільності трудових ресурсів, формування їх здатності до постійної самоосвіти, фахового зростання випускника"Завдяки інтеграції України до міжнародного освітнього простору вітчизняні стандарти освіти узгоджують із нормами світового співтовариства. Суспільство стає все більш людиноцентристським. Отже, «індивідуальний розвиток людини, особистості за таких умов $\epsilon, 3$ одного боку, основним показником прогресу, а 3 іншого - головною передумовою подальшого розвитку суспільства. Тому найбільш пріоритетними сферами у XXI столітті стають наука - як сфера, що продукує нові знання, та освіта - як сфера, що олюднює знання та насамперед забезпечує індивідуальний розвиток людини. Країна, що забезпечує пріоритетний розвиток цих сфер, зможе претендувати на гідне місце у світовому співтоваристві та бути конкурентоспроможною».

Перспективність цієї спеціальності зумовлена низкою об'єктивних чинників: зростанням обсягів техніко-економічної, фінансової, технологічної, наукової та іншої документованої інформації; посиленням значення високоякісного інформаційного забезпечення вищого керівництва всіх рівнів і напрямів соціального управління; впровадженням новітніх інформаційних технологій, застосуванням глобальних світових мереж, вдосконаленням засобів документування та розповсюдження інформації; зростанням ролі інформаційних процесів у всіх сферах людської діяльності. 
Створюються інформаційно-аналітичні підрозділи, інформаційно-рекламні агенції, розширюється коло центрів науково-технічної інформації.

Ключові слова: європейські освітні стандарти, академічна мобільность i доброчесність, міжгалузева компетентність випускника, уніфікація, інформаційно-аналітичні підрозділи, інформаційно-рекламні агенції.

Guzii Ivanna Stepanivna Doctor of philosophy, docent of the department of pedagogy and innovative education, lviv polytechnic national university, lviv, Chornovola St., 57, build. 36. tel.: (067) 675-93-59, e-mail: ivanna05071987@ukr.net, https://orcid.org/0000-0002-6886-6412

\section{GENERAL PROBLEMS OF PROFESSIONAL TRAINING OF FUTURE SPECIALISTS IN INFORMATION, LIBRARY AND ARCHIVAL AFFAIRS}

Abstract. At the present stage, the urgency of the focus of the educational process on the formation of competitive future specialists in information, library and archival affairs in the free economic zone is increasing. The society of accelerated obtaining of information emphasizes the indisputable benefits of mankind from the mass, superficial spread of education, often forgetting about no less indisputable negatives, and even just the losses that accompany this process. Ukraine's higher education system is "currently being modernized on the basis of European educational standards: academic mobility and integrity, interdisciplinary competencies of graduates, unification, unity of content and forms, educational and scientific support of labor mobility, formation of their ability to continuous self-education, professional growth of graduates". Ukraine's international educational space is harmonized with the norms of the world community. Society is becoming increasingly human-centered. Thus, "individual development of a person, personality under such conditions is, on the one hand, the main indicator of progress, and on the other - the main prerequisite for further development of society. Therefore, the most priority areas in the XXI century are science - as a field that produces new knowledge, and education - as a field that humanizes knowledge and, above all, ensures individual human development. A country that ensures the priority development of these areas will be able to claim a worthy place in the world community and be competitive "(Education of Ukraine in the XXI century: problems and prospects for development, 2013, p. 21).

The prospects of this specialty are due to a number of objective factors: the growth of technical and economic, financial, technological, scientific and other documented information; strengthening the importance of high-quality information support for senior management of all levels and areas of social management; introduction of the newest information technologies, application of global world networks, improvement of means of documentation and distribution of information; the growing role of information processes in all spheres of human activity. Informationanalytical subdivisions, information-advertising agencies are being created, the range 
of centers of scientific and technical information is expanding (Concept of professional orientation, 2017).

Keywords: European educational standards, academic mobility and integrity, interdisciplinary competence of the graduate, unification, information-analytical divisions, information-advertising agencies.

Постановка проблеми. Система вищої освіти України нині модернізується на основі європейських освітніх стандартів: «академічної мобільності і доброчесності, міжгалузевих компетентностей випускника, уніфікації, єдності змісту та форм, освітньо-наукового забезпечення мобільності трудових ресурсів, формування їх здатності до постійної самоосвіти, фахового зростання випускника» [1].

Сьогодні спостерігаємо гуртове формування змісту й усебічне обговорення громадськістю проекту стандарту професійної освіти, «але цей процес суттєво ускладнюється необхідністю гармонізації переліку професійних компетентностей майбутніх інформаційних працівників, що будуть навчатися в межах єдиної інтегрованої спеціальності. Аналіз пропозицій та зауважень науково-педагогічної громадськості профільних вишів до проекту стандарту підготовки бакалавра зі спеціальності 029 «Інформаційна, бібліотечна та архівна справа» дозволив визначити наявність прямо протилежних методологічних підходів до визначення змісту фахових компетентностей майбутніх випускників» [2].

Зважаючи на те, що спеціальність 029 «Інформаційна, бібліотечна та архівна справа» було введено до освітнього процесу без належного теоретичного обгрунтування як системного утворення і побудови освітньої професійної моделі, можна стверджувати, що ця спеціальність поки що не має «системного ефекту», а $\epsilon$ лише сумою елементів, 3 невідомими властивостями одного 3 них - «інформаційна справа». При введенні нових спеціалізацій у межах спеціальності варто брати до уваги дестабілізуючі механізми появи нових професій для розвитку інформаційного середовища. Їхня надлишкова диференціація та різноманітність можуть знизити ефективність функціонування інформаційного середовища, оскільки вузька спеціалізація призведе до нерозуміння його глобальних закономірностей [3].

Аналіз останніх досліджень і публікацій. Теоретичною основою для уточнення суті поняття «конкурентноздатність майбутнього фахівця інформаційної, бібліотечної та архівної справи» слугують різноаспектні дослідження щодо вирішення концептуальних проблем філософії освіти й професійної педагогіки, представлені науковими доробками вітчизняних і зарубіжних учених [В. Андрущенко, С. Батишев, Дж. Равен та ін.). Сутність інтеграції досліджували В. Безрукова, С. Гончаренко, Р. Гуревич, Ю. Козловський, Д. Коломієць, В. Ільченко, С. Клепко, Т. Стахмич та ін. Аналіз останніх наукових досліджень щодо підготовки майбутнього фахівця 
Журнал«Герспективита інновації наукиљ

(Серія«Гердагогіка», Серія «Гицхологія», Серія«Медицин»

№4(4) 2021

інформаційної, бібліотечної та архівної справи свідчить, що науковці значну увагу приділяють проблемі вдосконалення його професійної компетентності. Різні аспекти розвитку інформаційної, бібліотечної та архівної справи були предметом розгляду А.Кисельової, І.Матяш, О.Музичук, К.Селеверстової та ін.

Водночас питання підготовки конкурентоздатного фахівця за спеціальністю “Інформаційна, бібліотечна та архівна справа" у вищих технічних навчальних закладах на основі інтегративного підходу практично не досліджувалася, що i зумовило вибір тематики статті.

Мета статті - обгрунтування підготовки конкурентоздатного фахівця інформаційної, бібліотечної та архівної справи на засадах інтегративного підходу.

Виклад основного матеріалу дослідження. У сучасному світі значення освіти як найважливішого фактору формування нової якості економіки i суспільства зростає разом з ростом впливу людського капіталу. Українська система освіти здатна конкурувати із системами освіти передових країн. При цьому необхідна глибока i всебічна модернізація освіти 3 виділенням необхідних для цього ресурсів і створенням механізмів їхнього ефективного використання.

Освітня політика, відбиваючи загальнонаціональні інтереси у сфері освіти і презентуючи їх світовому співтовариству, враховує разом 3 тим загальні тенденції світового розвитку, що зумовлюють необхідність істотних змін у системі освіти:

- перехід до інформаційного суспільства, у зв’язку з чим особливого значення набувають фактори комунікабельності і толерантності;

- виникнення і ріст глобальних проблем, що можуть бути вирішені лише в результаті співробітництва у рамках міжнародного співтовариства, що вимагає формування сучасного мислення в молодого покоління;

- динамічний розвиток економіки, зростання конкуренції, скорочення сфери некваліфікованої і малокваліфікованої праці, глибокі структурні зміни у сфері зайнятості, що визначають постійну потребу у підвищенні професійної кваліфікації і перепідготовці працівників, підвищення рівня їхньої професійної мобільності;

- випереджальний розвиток освіти.

Професійна освіта, своєю чергою, ще не здатна належним чином вирішити проблему кадрів, зумовлену новими вимогами до рівня кваліфікації працівників. Водночас, багато випускників закладів професійної освіти не можуть знайти роботу, визначитися у сучасному економічному житті. В умовах економічного розшарування суспільства ці недоліки системи освіти підсилились нерівним доступом до якісної освіти залежно від доходів родини.

Результати аналізу напрацювань зарубіжних науковців також свідчать про відсутність виробленої комплексної, універсальної моделі сучасного 
інформаційного фахівця, яку можна було б застосувати у межах спеціальності 029 «Інформаційна, бібліотечна та архівна справа». Водночас варта уваги монографія Н. Лопатіної (2017) [4], в якій виконано багатоаспектний аналіз професійних ресурсів інформаційної діяльності, виявлено специфічну соціальну місію інформаційних спеціалістів, досліджено сучасні соціальні практики, в які «вбудовано» професійні ресурси інформаційної діяльності.

Об'єктивно «легітимним» інформаційним фахівцем у новоутвореній спеціальності $\epsilon$ документознавець. Розвиток спеціальності «Документознавство та інформаційна діяльність» відбувався динамічно, охоплював державні та приватні заклади вищої освіти (далі ЗВО) із вираженою тенденцією введення спеціальності у негуманітарних закладах вищої освіти. Навчальні плани, в яких був наявний паритет двох дисциплінарних блоків - документознавчого та інформаційного, відображали об’єктивний процес розвитку від концепції документаційного до концепції інформаційного забезпечення управління, що уможливило диверсифікацію діяльності документознавців, цілком відповідало назві спеціальності й дало змогу розглядати їх як фахівців 3 інформаційного забезпечення управління [5].

Діяльність управлінських структур грунтується на створенні й використанні інформації у будь-якій організації i сконцентрована у документах. Завдяки чітко організованій роботі 3 документами керівник може у будь-який момент отримати вичерпну інформацію про діяльність підприємства або організації. За відсутності встановленого порядку роботи 3 документами керівництво підприємства не матиме змоги приймати юридично й організаційно виважені рішення й уся подальша діяльність такого підприємства матиме хаотичний характер [6].

Розв'язувати проблеми впорядкування діяльності 3 документами на підприємствах різної форми власності в Україні повинні спеціалістидокументознавці, які «професійно володіють методами аналізу документів, методами, що забезпечують звичайний та електронний документообіг, методами створення документів із використанням різних стилів опису та оформлення. Сучасні працівники служби документації повинні бути готові до ведення інформаційної боротьби 3 конкурентами, володіти глибокими знаннями з державної мови та документаційної лінгвістики»

Такі фахівці повинні досконало знати чинні стандарти і нормативні матеріали у галузі створення документів, володіти текстовими і графічними редакторами, вміти працювати у комп'ютерних мережах тощо. Це зумовлює необхідність виконання наукових досліджень 3 проблеми формування та оновлення освіти фахівців інформаційної, бібліотечної та архівної справи. За таких умов доцільне дотримання бібліоцентричних форм розвитку бібліотечно-інформаційної освіти у колі цілісного інтегрованого фаху, позаяк 
Журнал«Герспективита інновації наукиљ

(Серія«Гедагогіка», Серія «Гиихологія», Серія «Медицинв»

№4(4) 2021

неупереджене посилення інформаційно-аналітичної діяльності новітніх наукових i науково-технічних бібліотек, забезпечених усім спектром автоматизованих інформаційно-комп’ютерних технологій, неабияк збільшує їхні виробничі здібності як абсолютних суб’єктів ринку інформації. Ідеться про укомплектування та зберігання рукописних i друкованих культурних надбань, краєзнавчої літератури, їх наукове розроблення, каталогізацію, оцифровування безцінних книжкових пам'яток, створення електронних архівів документації тощо.

Попит на інформаційні продукти та послуги зростає. Це впливає на розвиток мотивації документно-інформаційної діяльності. Бібліотека стає найбільш потужним документно-комунікаційним інститутом. Бібліотечні функції, властивості яких пов’язані з універсальністю документа - основного елемента системи документної комунікації, сприяють інтеграції соціальних інститутів на науково-методичному, освітньому та прикладному рівнях [6].

Тривалий час базовою дисципліною у підготовці фахівців для цієї сфери було Документознавство (див. Додаток Б).

Гайсинюк (2003) [7].розглядає проблематику документознавства як однієї з базових професій в умовах інформатизації суспільства та базової навчальної дисципліни у підготовці (перепідготовці) фахівців для цієї сфери, враховуючи необхідність виявлення інформаційних потреб, їх задоволення та подальшого розвитку, а також доведення спеціальної інформації до відповідних категорій споживачів. Авторка розглядає місце документознавства як галузі наукового знання i навчальної дисципліни; питання поточного освітнього процесу, що знайшли відображення в публікаціях; систему понять, пов'язаних 3 термінами «документ» i «документознавство». «Становлення документознавства як навчальної дисципліни i окремої багатоаспектної галузі знань відбувається під впливом багатьох суміжних наук $\mathrm{i}$ дисциплін, що зумовлює необхідність термінологічних запозичень з різних джерел. Розмаїтість трактувань характерна i для понять «інформатика», «кібернетика», «Інтернет», «інформаційний простір», «інформаційна система». Розкрити їх зміст вдається лише з найбільш адаптованих до досліджуваної сфери семантичних позицій».

Вимоги до сучасного фахівця передбачають його високу продуктивність, гнучкість, здатність адаптуватися до швидких змін умов функціонування галузі. Людству новітньої епохи необхідне нове мислення та ціннісні орієнтири «для становлення нового типу глобальної спільноти людей, здатних подолати те, що їх роз'єднує. Збільшення можливостей доступу до засобів отримання, зберігання та відтворення інформації подібне цунамі, що стимулює спільноту віднаходити об'єднавчі фактори окремих громадян нашої планети» [8]. Сьогодні система інформаційного забезпечення потребує фахівців, здатних опрацьовувати значні обсяги інформації, класифікувати та використовувати їх. 
У зміст терміна «конкурентоздатність» закладено філософський, психологічний, педагогічний та економічний рівні, що полягають у досягненні продуктивного результату - конкурентоздатності товарів і послуг. «Конкурентоздатність» із погляду особистісного підходу становить особисту якість людини, потрібну для сталого фахового розвитку майбутніх фахівців інформаційної, бібліотечної та архівної справи. Діяльнісна складова такого феномена полягає в досягненні будь-яких результатів і супроводжується певними свідомими й мотивованими діями, завдяки різним способам, прийомам, методам у тому чи іншому виді діяльності. Для ефективної конкуренції за конкретної діяльності в конкретних умовах необхідні знання, вміння, навички (компетенції й компетентності), метапрофесійні якості, що й підтверджує компетентнісну основу конкурентоздатності майбутнього фахівця інформаційної, бібліотечної та архівної справи.

Сфера майбутньої професійної діяльності фахівця інформаційної, бібліотечної та архівної справи характеризується наданням робочих місць у галузі інформаційної, бібліотечної та архівної справи, зокрема: менеджмент інформаційних продуктів та послуг, управління інформацією, PR-технології, керування спільнотами, адміністративний менеджмент, державне управління, інформаційний консалтинг, data-менеджмент. Це передбачає здатність вирішувати складні спеціалізовані завдання та практичні проблеми під час професійної діяльності у галузі інформаційної, бібліотечної та архівної справи або у процесі навчання, що зумовлює застосування теорій та методів інформаційної, бібліотечної та архівної справи і характеризується комплексністю та невизначеністю умов (Освітньо-професійна програма, 2016. Водночас, кожен випускник має бути конкурентоздатним фахівцем по відношенню до обраного виду професійної діяльності, забезпечувати конкурентоспроможність продукції у межах виробництва.

Загальні положення інтегративного підходу будуть правильно використані тільки у тому випадку, коли існує чітке розуміння його суті: найкраще забезпечення та реалізація інтегративного підходу до професійної підготовки будуть далеко не такими ефективними, якщо передбачена тільки зовнішня, формальна сторона інтеграції. Подання інтегративного змісту 3 використанням відповідних інтегрованих форм i методів $\epsilon$ лише передумовою успішної інтеграції.

Надзвичайно важливою і необхідною умовою є розуміння потреби у забезпеченні інтеграції не лише у процесі викладання навчальних дисциплін та реалізації інтегративних форм і методів, але й у формуванні усвідомлення здобувача освіти, розвитку системи його власних уявлень. Такий процес $\epsilon$ складнішим, але набагато ефективнішим і дозволяє використати практично усі переваги інтегративного підходу.

Суттєвим чинником реалізації інтегративного підходу є передбачення можливостей вилучення старих та включення у програмний навчальний 
Журнал«Герспективитаінновації науки»

(Серія«Гедагогіка», Серія«Гцихологія», Серія«Медицинв»

№4(4) 2021

матеріал нових знань. Для фахівців інформаційної, бібліотечної та архівної справи ця теза $є$ особливо актуальною, оскільки вони є джерелом нової інформації для інших спеціальностей та галузей знань. Отож, завдяки інтегративному підходу до професійної підготовки майбутніх фахівців інформаційної, бібліотечної й архівної справи $\epsilon$ змога повсякчас поповнювати знання й розширювати практичні вміння та навички; формувати конкурентоспроможного фахівця. Водночас присутність у професії компонента архівної справи розширює можливості згортання інформації.

Інтегративний підхід у професійній підготовці майбутніх спеціалістів інформаційної, бібліотечної й архівної справи доцільний власне у поєднанні усіх його видів. Інтеграція лише знань чи лише форм, очевидно дає певний позитивний ефект, однак він не може суттєво вплинути на результат навчання. Власне тому реалізація інтегративного підходу будується за строгою схемою, яка придатна для усіх спеціальностей, а далі розпочинається варіативний процес адаптації інтегративних впливів на формування професійної підготовки конкретної професії. Загальна схема містить головні елементи інтеграції у такій послідовності:

- теоретичне обгрунтування можливостей інтеграції до формування змісту навчання шляхом дослідження теоретичних засад розробки змісту навчання та виявлення доцільних для інтегрування елементів;

- розроблення алгоритму виділення елементів інтеграції змісту навчання та вибір відповідного інструментарію;

- визначення опорних методологічних положень та принципів для побудови інтегрованого змісту навчання;

- виділення елементів знань, які підлягатимуть інтеграції;

- виділення елементів умінь і навичок, які підлягатимуть інтеграції;

- визначення засобів навчання, які оптимізуватимуть результат інтеграції знань, умінь і навичок;

- обгрунтування вибору методів та вибір шляхів їх інтеграції у процесі засвоєння змісту навчання;

- виявлення існуючих вже інтегрованих методів навчання;

- обгрунтування та вибір форм навчання 3 поясненням можливостей їх подальшої інтеграції;

- виявлення вже існуючих інтегрованих форм навчання;

- забезпечення комплексного використання інтегративного підходу у взаємозв'язку змісту, форм, методів та засобів навчання.

Інтегративний підхід до викладання навчальних дисциплін, на яке спрямовує сучасна дидактика, переростає від узгодження змісту освіти до глибокої взаємодії, обгрунтованої інтеграції знань, умінь, навичок та елементів мислення майбутнього фахівця.

Таким чином, у підрозділі проаналізовано можливості застосування 
інтегративного підходу у професійній підготовці майбутніх фахівців інформаційної, бібліотечної та архівної справи, а також виокремлено основні напрямки його застосування, досліджено інтеграцію професій, знань, умінь.

Висновок. На основі здійснених обгрунтувань суть поняття «конкурентоздатність майбутнього фахівця інформаційної, бібліотечної та архівної справи» конкретизуємо як інтегративну особистісну якість, яка усвідомлено виражається мотивованими діями в конкретних умовах професійного та соціально-економічного середовища й передбачає ефективність у досягненні результату завдяки комплексній мобілізації й функціональному спрямуванні ресурсів її структурно-змістовних компонентів.

\section{Лimepamypa:}

1. Астахова, В. (2008). Освіта безперервна. Соціологічна енциклопедія. (с. 263-264). Київ, Україна: Академвидав.

2. Соляник, А. А. (2017). Сучасні проблеми стандартизації вищої бібліотечноінформаційної освіти в Україні. Сучасна інформаиійно-бібліотечна освіта: європейські оріснтири: Матеріали VІІ Міжннародної науково-практичної конферениії. (с. 11-16). Київ: УБА.

3. Матвієнко, О., \& Цивін, М. (2016). Спеціальність 029 «Інформаційна, бібліотечна та архівна справа»: у пошуках «інформаційного фахівця». Вісник Книжккової палати, 10. 32-35.

4. Лопатина, Н. В. (2017). Новые профессии в информаиионной сфере: опыт аналитикопрогностического исследования. Взято 3: http://www.fact.ru/www/arhiv9s2017.htm

5. Дубова, С. В. (2010). Підготовка документознавиів для сфери державного управління в Україні (1995-2008 рр.). (Автореф. дис. канд. іст. наук). Державна академія керівних кадрів культури і мистецтв, Київ.

6. Бірюкова, Т. Л., \& Якубовська, М. Г. (2016). Інтегративні властивості бібліотечних функцій: імплементація в освітньому електронному середовищі. Вісник Одеського наиіонального університету, Серія: Бібліотекознавство, бібліографознавство, книгознавство, $21(2), 93-108$.

7. Гайсинюк, Н. А. (2003). Педагогічні засади підготовки документознавиів в умовах інформатизаиії суспільства. (Автореф. дис. канд. пед. наук). Київський національний університет культури і мистецтв, Київ.

8. Маклюэн, Г. М. (2005). Галактика Гутенберга: становление человека печатающего. Москва, Россия: Академический проект.

\section{References:}

1. Astakhova, V. (2008). Osvita bezperervna [Education is continuous]. Kyiv, Ukraine: Akademvydav [in Ukrainian].

2. Solyanik, A.A. (2017). Suchasni problemi standartizaciï vishhoï bibliotechno- informacijnoï osviti v Ukraïni. Suchasna informacijno-bibliotechna osvita: evropejs'ki orientiri [Modern problems of standardization of higher library and information education in Ukraine. Modern information and library education: European guidelines]. Materiali VII Mizhnarodnoï naukovo-praktichnoï konferenciï Proceedings of the VII International scientific-practical conference. Kyiv: UBA [in Ukrainian].

3. Matvienko, O., \& Tsyvin, M. (2016). Special'nist' 029 «Informacijna, bibliotechna ta arhivna sprava»: u poshukah «informacijnogo fahivcja» [Specialty 029 "Information, library and archival affairs": in search of "information specialist"]. Visnik Knizhkovoï palati- Bulletin of the Book Chamber, 10. 32-35 [in Ukrainian].

4. Lopatina, N.V. (2017). New professions in the information sphere: the experience of analytical and prognostic research [Novye professii $v$ informacionnoj sfere: opyt analitikoprognosticheskogo issledovanija]. URL: http://www.fact.ru/www/arhiv9s2017.htm [in Russian]. 
5. Dubova, S.V. (2010). Pidgotovka dokumentoznavciv dlja sferi derzhavnogo upravlinnja v Ukraïni (1995-2008 rr.) [Training of document specialists for the sphere of public administration in Ukraine (1995-2008)]. Extended abstract of candidate's thesis. Kiev: State Academy of Management of Culture and Arts [in Ukrainian].

6. Biryukova, T.L., \& Yakubovskaya, M.G. (2016). Integrativni vlastivosti bibliotechnih funkcij: implementacija $\mathrm{v}$ osvitn'omu elektronnomu seredovishhi [Integrative properties of library functions: implementation in the educational electronic environment]. Visnik Odes'kogo nacional'nogo universitetu, Serija: Bibliotekoznavstvo, bibliografoznavstvo, knigoznavstvo - Bulletin of Odessa National University, Series: Library Science, Bibliography, Bibliography, 21 (2), 93-108 [in Ukrainian].

7. Gaisinyuk, N.A. (2003). Pedagogichni zasadi pidgotovki dokumentoznavciv v umovah informatizaciï suspil'stva [Pedagogical principles of training document specialists in the conditions of informatization of society]. Extended abstract of candidate's thesis. Kiev: State Academy of Management of Culture and Arts [in Ukrainian].

8. McLuhan, G. M. (2005). Galaktika Gutenberga: stanovlenie cheloveka pechatajushhego [Gutenberg's Galaxy: the Formation of the Printer Man]. Moscow, Russia: Academic project [in Russian]. 